\title{
POTENTIAL OF NEW INSTITUTIONAL ECONOMICS FOR RURAL COMMUNITY DEVELOPMENT
}

\author{
P. Eko Prasetyo ${ }^{1 *}$, Adryan Setyadharma ${ }^{1}$, and Nurjannah Rahayu Kistanti ${ }^{1}$ \\ ${ }^{1}$ Department of Development Economics, Faculty of Economics, Univeritas Negeri Semarang, \\ Indonesia
}

\begin{abstract}
Rural economic inequality is a fundamental problem which makes it important to seek its causes and find its policy solutions immediately. The new institutional economic potential development policy is the right choice. The purpose of this article is to explain more broadly the importance of new institutional economic potential in developing rural communities. Especially, to explain various economic dimensions of new institutions in a comprehensive manner in determining the level of community development. This research method used structured survey that has been well-designed and measured for data collection, variable measurement, and data analysis. Quantitative and qualitative data are gathered by using integrated methods between various disciplines; economics-sociology and economics-geography. Further, to interpretation the data, we used economic and cultural concepts; informal economy, new institutional economics, gravitational economics and cultural anthropology. Then, the method of analysis is path analysis using recrusive form of correlation model with multiple path equation systems. The main research results show that the new institutional economic potential is a key factor in developing rural communities and reducing inequality. Besides, the new institutional economics will encourage economic growth and public welfare
\end{abstract}

\section{INTRODUCTION}

Currently, rural communities in Indonesia are not only experiencing complex problems, but also interesting challenges to study and develop such as the increase of economic inequality, and the decline of social capital. Other problems that cannot be taken for granted are poor commercial infrastructure, limited social networks, increasingly loss of productive personnel, and the limitation of other facilities. Not only rural development policies have been implemented in various ASEAN member countries, but also have become priorities and industrialization's complementary. These efforts contribute to higher inclusive growth and more employment in rural areas (Thanh, 2016). The aim of rural development in Indonesia is to encourage quality economic growth; to reduce unemployment, poverty and

\footnotetext{
* Corresponding author: pekoprasetyo@mail.unnes.ac.id
} 
inequality. Many policy programs for rural areas have been carried out such as counseling, education and training, various grants and subsidized soft loans. However, the program has not helped many rural communities to rise and develop independently. The success of each program can vary, even in the same geographic area. To help participate in solving the problem, it is proposed to focus on the role and function of the potential of "institutions" especially through the new institutional economics. The urgency of institutions in the broadest sense, can be at the center of all efforts in developing rural communities. Furthermore, this article proposes a new institutional economics as a new reference that can be used to encourage economic development and improve the welfare of rural communities.

Rural economic development is a part of community development. The economic development of rural communities is as a process of increasing income and living standards and the welfare of rural communities followed by increasing quality of life and quantity of settlements, better quality of social, psychological and cultural institutions in rural communities. Community development is a process where people are together with the government and other stakeholders to improve the socio-economic and cultural conditions of community members (Latopa, 2015). This improvement will determine their better choice and create an environment which make people can use their full potential to lead productive lives (Shaffer 1989). Rural community development is a process carried out by community members. This is a process in which local communities cannot only create more jobs, income, and infrastructure, but also help their communities become fundamentally better and are able to manage change (Cavaye, 2006). The function of economic institutions in society is as an institution that provides security of ownership rights and relatively equal access to economic resources to the wider community (Netar, 2017). The result of Netar's research (2017) explains that there is a large impact from the institutions that exist in the community on livelihoods in rural areas

The economic development of rural communities will certainly involve active participation and many institutional elements of related community development such as social capital, human capital, social networks, economic institutions, entrepreneurial business opportunities or rural industries and so on. The article is to describe the problem in achieving economic development of rural communities and community development. Specifically, it is to describe the role of local wisdom of social capital in the community and new institutional economics potential in the development of rural communities. According to Netar (2017), the role of social and economic institutions in a society will dominate the economic development process. They determine attitudes, motivations and conditions for development. If the institutions are elastic and encourage people to take advantage of economic opportunities and further to lead a higher standard of living and inspire them to work hard, economic development will occur and vice versa. However, this problem has been properly observed by UNO that economic development is not possible without supporting environment (Netar, 2017)

The basic concept of new institutional economics (NIE) is the economic behavior of a person or group which is strongly influenced by certain institutions. This institution is very strong and in this case are interpreted as "rules of the game" in a community group, both formal and informal. Therefore, the key to the success of economic development for the development of rural communities through new economic institutions requires sufficient prerequisites as well as the support of all institutional elements that exist in society and active participation of the community productively. All individuals in society and institutional elements are expecting progress and must make changes that are beneficial to the progress of society. That is, the economic role of the new institution is taken as a facilitator or rules of the game; to overcome common inequality, prosperity and justice. Meanwhile, every behavior of the active participation of individuals and society is a determinant of institutional progress. Because institutions are inanimate objects, institutions 
cannot develop if there are no individuals or groups in the community who develop them, and conversely individuals and community groups will be difficult and cannot develop well if existing institutions do not facilitate the individual or group to be actively participate and take action for the progress. In other words, the new institutional economics is proposed as a rule of the game in encouraging the active behavior of the community to create business opportunities, efficiency, influenceiveness, productivity, economic growth and competitiveness and shared prosperity.

The research argues that both novelty and empirical institutional performance of the Indonesian central government are ininfluenceive and inefficient, and are unable to reach rural areas, so that the inequality in rural areas increases. This argument is supported by the result of a research (Yildirim, 2016) which concludes that developing country institutions are generally less influenceive. In developing countries the quality of service is bad as well as its bureaucracy. It is high cost, weak human resource capacity, unskilled, corrupt, and the existence of manipulation in the justice system. So that, the level of social trust is low and the existence of institutions does not have adequate legal regulations and sanctions. Hence, it is proposed that social capital, human capital, entrepreneurship, and new institutional economics are the pillars of sustainable economic development that are expected to be able to increase rural economic growth and reduce inequality. This argument is supported by the result of a research (Raja, 2014) which stating that if natural capital, physical capital and human capital are the wealth of the nation, social capital contributes more to harmonious growth. Raja, (2014) emphasizes that with the new institutional economics framework, social capital is a driver of sustainable development. The aim is to introduce to potential institutions; new social capital, human capital, entrepreneurship and institutional economic framework in Indonesia which can be the main sources of sustainable development and reduction of inequality through rural community development efforts

\section{Literature review}

Institutional theory has been increasingly used in research and entrepreneurial implementation, (Bruton, 2010). Based on literature studies, the emergence of the term "institutional economics" (institutional economics) was first introduced by Walton Hamilton in 1919. The well known institutional school of economics are Thorstein B. Veblen, Wesley Mithell and John R. Commons (Rutherford, 2001). However, this institutional school of economics did not develop and was inferior to the Neo-Classical School with econometric tools and welfare economics by J.M. Keynes. Further, in 1970s, this institutional economy reappeared with a more standard concept and as a center to discuss ideas and had a greater economic impact, so that since this emergence, it is often known as New Institutional Economy (NIE) and in 1970s was considered Old Institutional Economics (OIE). The OIE person who is considered the most powerful and influential and can also be called the father of institutional economics is Thorstein Bunde Veblen (18571929). Whereas, the famous followers of Veblen are like; Joseph Schumpeter, Gunnar Myrdal, and Kenneth Galbraith. However, in various literatures, they are often referred to the flow of Islamic Institutions.

The emergence of NIE is a success story which have been through many stages (Menard, 2018). The emergence of the NIE as a center for new ideas, there are not only many institutional research programs running, but also many competing ideas (Williamson, 2000; Richter, 2005). There are famous NIE figures such as Douglas C. North, Ronald Coase; Elinor Ostrom; and Oliver E. Williamson (Richter, 2005). Also, there are several important functions and important roles that NIE stands for as arguments which are used as the rationale. First, NIE is an effort to incorporate institutional theory into the economy. However, NIE modifies and expands the NCE theory to be able to overcome and deal with 
various problems (North, 2003). What is built and maintained is the basic assumption of scarcity and competition as the basic theory of competition in microeconomics. The NCE assumption is instrumental rationality. Second, NIE is more flexible because it emphasizes "rules" or economic policies and not the dominance of free market roles. Where the institutional framework determines the types of skills and knowledge that are considered to have maximum results (North, 2003). Third, NIE is important because it is built humanistically by formal and informal forces to improve economic growth, competitiveness and shared equity (Acemoglu, 2005, Prasetyo, 2019). Another argument is that the new institutional economics approach is more multidisciplinary in nature, namely placing economics in the framework of a unity with other social sciences such as; sociology, anthropology, geography, history, politics, law and real life culture of the local community.

There is small difference between OIE and NIE namely; that the emergence of OIE tends to be a reaction to the feeling of dissatisfaction with the flow of Neo-Classical (NCE) which is actually a continuation of the flow of classical economics. Whereas, the emergence of NIE tends to be more constructive, perfect and complete. There are four basic theoretical concepts used by the NIE school in discussing the economic behavior of society, namely; (1) transaction cost theory, (2) property rights theory, (3) public choice theory, and (4) game theory, (Williamson, 1985, 2000; Kim, 2005). The first three bases are often referred to as the NIE golden triangle (Menard, 2018). Meanwhile, another difference between OIE and NIE is that the NIE school still uses two basic Neo-Classical assumptions that are important namely; rational individual behavior and the existence of a clear individual preference function. Based on these differences, the NIE is often considered not to create conflict with NEC and its nature as development, but it is refining and completing. Williamson (2000) has introduced the evolution of the NIE theory through four levels of "social analysis", and the first level is considered the lowest level is; social theory namely; as informal rules that are inherent in the local community such as tradition, norms, customs and religion. This level moves very slowly. Then, the second level is; economics of property rights, the third level is transaction cost economics, and the fourth level as the highest level is resource efficiency and incentive structure originating from neoclassical economics or agency theory.

Institutions are humanly designed boundaries forming interactions among communities, both formally and informally and their enforcement characteristics (North, 1994). Institutions are the center of many rural development efforts and offer a place of reference for community members, development researchers, and practitioners to develop a sense of norm and common understanding to work (Meador, 2017). Meanwhile, social capital is the main source of contribution to harmonious economic growth (Raja, 2014). Therefore, it is important to gain insight into the relationship between social capital and rural welfare (Ali, 2006). The Estrin Research Result, (2016) states that it is necessary to strengthen the importance of human capital's ability to enter entrepreneurship, and institutions act as important contingencies. This phenomenon strengthens the argument of the human capital theory into social entrepreneurship. Furthermore, Nielsen (2007) asserts human and social capital in a guideline for intervention in policy implementation. It is very useful to link with systemic approaches such as; system innovation, business systems, and also social capital theory as an intermediary theory in the context of intermediate applications. Whereas, at the high level of adaptation and flexibility in the global market, it needs to be combined with high social benefits and high wage rates, as a balance of human capital. In addition, entrepreneurial incentives and individual responsibilities must be also strengthened (Nielsen, 2007).

Economic development is a part of community development aiming to build five important things, namely; physical, financial, human, social and environmental (Cavaye, 
2006). According to Cavaye (2006), the development of rural local industries involves relatively small industrial or institutional group facilities such as market alliances, and this is part of economic development. Through participation and social networks, they build social capital and new skills to build human capital. Furthermore, they develop new economic options in the form of institutions to build physical and financial capital and to improve their environment. Based on all the literatures discussed above, the framework of this research is that; the existence of the potential of social capital, human capital and social networks owned, then they build entrepreneurial business opportunities in the rural area and market alliances as a forum for rules of the game. All of these activities are processes of economic development as part of developing rural communities. Meanwhile, the role and function of the new socio-economic institutions dominate the process of economic development

\section{Methodology}

\subsection{Structural equation model.}

This research is an exploratory research using a quantitative approach. The main types of explanatory variables are; social capital, networking and human capital. This main explanatory variable is used to explain the efforts to establish entrepreneurial business opportunities, and new institutional economics, as a way to produce productive economy for the development of rural communities. Further, the main key variable is the new institutional economics variable and it refers to endogenous variable. In the path analysis research model, the explanatory explanatory variable can be considered as an exogenous variable that will determine the formation of endogenous variables. There are two endogenous variables, namely the main endogenous variables, namely the new institutional economics, and entrepreneurial business opportunity variables as the second endogenous variable as well as exogenous variables or moderators of the new institutional economics variables. Based on this information, the structural equation model is as follows

$$
\begin{aligned}
& Y=\rho_{Y X 1} X 1+\rho_{Y X 2} X 2+\rho_{Y X 3} X 3+\varepsilon_{1} \\
& Z=\rho_{Z X 1} X 1+\rho_{Z X 2} X 3+\rho_{Z Y} Y+\varepsilon_{2}
\end{aligned}
$$

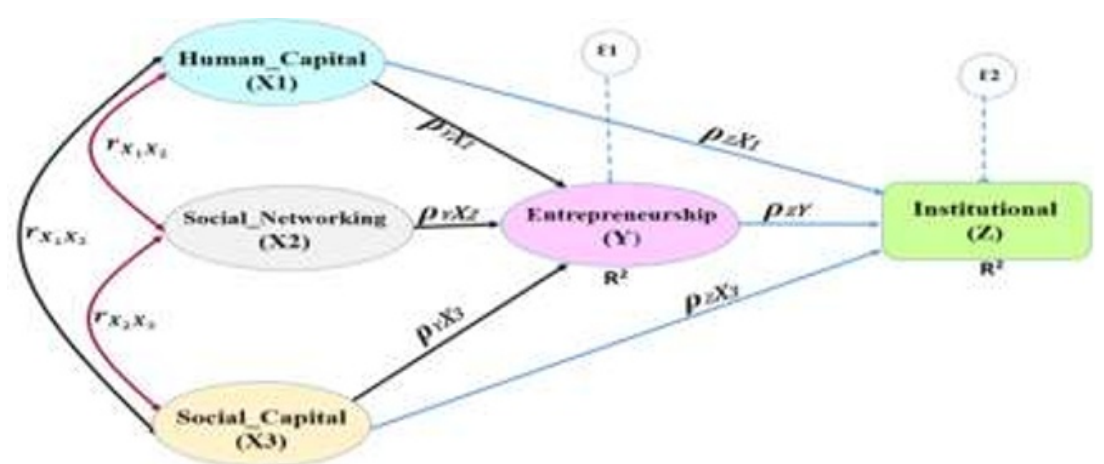

Fig.1. Path analysis of the recrusive form correlation model with multiple path equations The acknowledgements should be typed in 9-point Times, without title.

Based on figures-1, this research aims to analyze the direct influence, indirect influence and total influence on the new institutional economics. In quantitative analysis of the path analysis model is used to strengthen the argument and to show that standard coefficients can be used and the case of multicollinearity can be reduced 


\subsection{Research design and explanation}

Based on the use of the level of depth of analysis and its type of data, this research tends to be exploratory research designed by the use of an explanatory quantitative descriptive research approach. The main purpose is to explore and analyze deeper the problems of economic development as an effort in developing rural communities. Various issues in the village that have been revealed above are especially; the problem of low economic growth, and high unemployment, poverty and inequality. These must be resolved through economic development so that rural communities are able to develop independently to improve their standard of living and welfare. As economic development is part of community development, the main institutional variables of the new institutional economics potential are proposed as a solution through rural economic development. Because the purpose of the research is to explore, analyze deeply the various factors or other variables that are related and influence the main variables of the institution, the other variables used are more referring to the model (1) and (2). The position of the institutional variable (Z) is an endogenous variable. While some other variables as explanatory (exogenous) are; Human capital (X1), Social networking (X2), Social capital (X3), and entrepreneurship, (Y).

Social capital variables, social networks and human capital as the main key variables used in this research refer to the basic model of Wiliamson theory $(1985,2000)$. In the initial stage (level 1), this research was designed with the basic concept of "social theory" as described in the Williamson model. That is, collaboration between the main exogenous variables will encourage the formation of entrepreneurial business opportunities in a rural area. Furthermore, in order for the existence of the entrepreneurial business to develop institutional factors which are good, safe and fair. One of the institutional factors referred to is the new institutional economy as a platform and a solution. For the needs of in-depth analysis, primary data are needed and secondary data as supplementary one. The method used is the socio-economic and economic-geographic science approach. While the analytical method tends to be a science approach; economics and economics-sociology. Furthermore, for the purposes of quantitative-descriptive-exporatory analysis, all variables are quantitative and the data tend to be measured through an economic value approach using the gini ratio index method.

\section{RESULTS AND DISCUSSION}

\subsection{Descriptive results and discussion}

Economic development is regarded successful if it is able to improve the standard of living and welfare of the community to the rural area. Community welfare is an economic and social dimension. This means that there is a relationship of interdependence between economic growth, economic development and social development. Thus, to achieve good economic development in rural communities, it is not enough to only create economic growth, but it also its growth has to be high, human quality, humanistic principles are maintained and environmentally friendly and social condition is improved. Achieving a high level of economic growth is indeed important, but it is more significant it also improve the quality and the benefits of economic growth itself. If the high economic growth can be achieved, but economic development is not able to reduce the problem of unemployment, poverty and inequality, then this economic development cannot be said successful (Seers, 1979, Chibba, 2008). According to Dudley Seer (1979), the goal of economic development is to reduce poverty, unemployment and inequality. According to Seers (1969), if one or two or even three of these conditions are not available, then development has not succeeded, even though the income per capita has increased in large numbers (Chibba, 
2008). Figure 2 shows conditions in Indonesia. In the last 15 years (the era of President SBY and Jokowi), it is found that the economic growth is able to reduce poverty and unemployment, but inequality remains stagnant at a high level, above (0.39), even in rural level of inequality tends to increase. If you refer to the opinion of Dudley Seers, then economic development in Indonesia cannot be said successful.

To make the process of economic growth give a positive influence, it has to be also accompanied by the increase of life quality per capita and a policy of national resource utilization, to achieve individual and social progress in each country (Haller, 2012). Quality of life is a multi-dimensional concept based on a complicated causal relationship of reciprocal relationships of variables that are difficult to measure because they are created from two subjective personal and psychological dimensions (Murgas, 2015). Therefore, the most important part of life quality is the phenomenon of achieving a better life. Thus, Indonesia must strengthen the economic and social institutional system, as well as good and right economic and political governance. The government's policy program in providing village funds is a good program, but unfortunately, its governance is not implemented properly making it have no positive impact on reducing poverty, unemployment and inequality in the rural areas. This problem is generally caused by the problems of economic and political institutions even though the socio-cultural institutions are strong. However, the impact of governance on development is still subjective, complex and not well understood and correct. For example, there is still misuse of village funds. This is proven by the condition of economic and social development in rural areas which is still challenging and it is suspected that the quality of government institutions are still severe. For instance, corruption cases and also inefficient administrations from the national to the local level

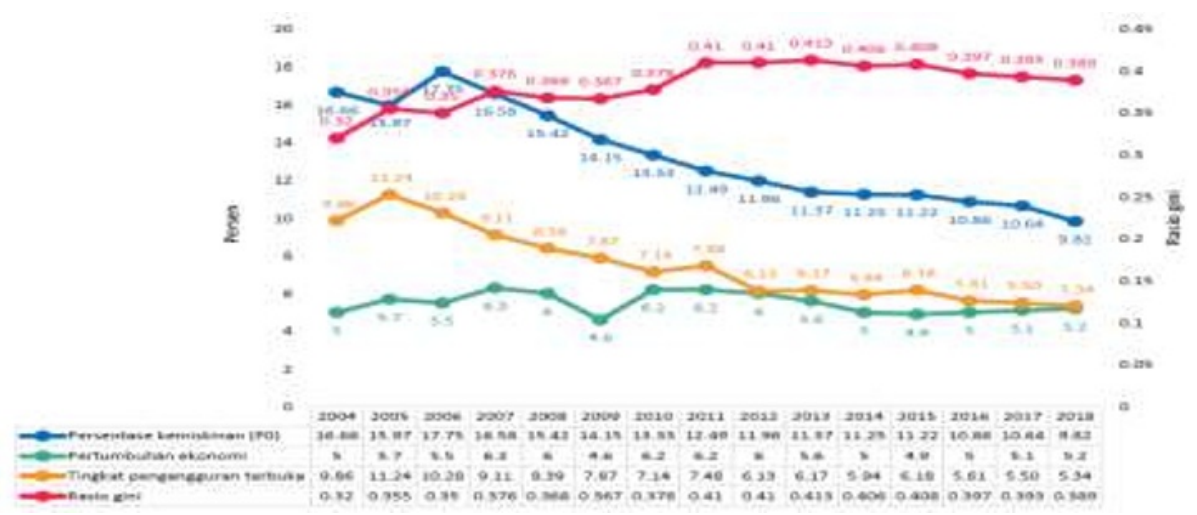

Fig.2. Description of economic quality growth, unemployment, poverty, and inequality.

Based on the above figures and explanations, it can be stated that the unsuccessful implementation of central government policies in rural areas is due to the fragility of economic and political institutions in the local as a reflection of the weakness of national political institutions. To conclude, there is less awareness of economic and social policies in which they are the key to the success of humanist and sustainable economic development. The quality of economic growth in Indonesia as a sufficient condition in the success of economic development because of human capital (Prasetyo, 2008). Meanwhile, social capital is the main source of contribution to harmonious economic growt (Raja, 2014). Therefore, economic, social, political and cultural institutions in the rural areas must be formed and strengthened by the factors of human capital and social capital in the local community as the strength of the local wisdom. If the institution formed is not supported by the strength of local wisdom from both human capital and social capital factors, it will still 
be easily fragile. This is due to human capital and social capital are the main investments in driving the success of economic growth and social economic development.

Indonesia's vision states that people are the main source of development because the goal of development in Indonesia is to develop Indonesian humanity as a whole and to develop the entire Indonesian community. So that, persons are the main subject and not as objects in the development. With the improved human and social capital, the creativity, innovation and productivity will be stronger and the quality of economic growth will be increasingly high. In my opinion, economic growth in Indonesia is not yet qualified because of economic growth has not been able to encourage the success of achieving the objectives of economic and social development. The high level of income inequality is a proof that even equity-economic achievement can still be declared unsuccessful especially the prosperous social equity is still not fulfilled. I suggest that there are two main reasons namely the quality of human capital and social capital and also the in accurate measurement. Economic growth as measured by Gross Domestic Product (GDB) in Indonesia is inaccurate and can be misleading, preferably economic growth is more real if measured by the Gross National Product (GNP).

It is argued that the attention of Indonesia today and in the future is not only given to to achieve high economic growth as measured by DGP, but also economic growth should be focus on quality. It should be immediately known who are the biggest dominant players and tthose taking the benefits of the achievement of GDP; what kind of mechanism is formed in achieving economic growth as measured by GDP? What mek the rural communities cannot enjoy the results of these economic growth achievement. In other words, if only a high economic growth program could be achieved, it would still be difficult to reduce development problems, especially it is still difficult in reducing income inequality. Therefore, it takes courage and commitment of all elements of the Indonesians to build the capacity of quality human resources and social capital, and the courage to change the mechanism of how to measure economic growth to a more real thing. Without commitment, the biggest bonus demographic that will occur in 2030 can only be a burden for government, and become an object of development and instead of the main subject and capital in development.

\subsection{Quantitative results and discussion}

The purpose of using the path analysis model is to explore, detect and strengthen the description of the dependence between the various economic phenomena described above. Basically there are three forms of the path analysis model namely; (1) correlated path model, (2) mediated path model, and (3) independent path model. This is because the exploratory research design referred to is to multiply more in the role of variables in terms of the level of relations and at the same time the degree of influence of exogenous variables on endogenous variables both; direct, indirect and total influence. The meaning of the recrusive path analysis model is the causal relationship between endogenous and exogenous variables is in the same direction. Although it is assumed that the direction of the relationship can be of two-way causality, but to make it shorter and easier to understand, they were only selected and presented in the form of a recrusive model only. Furthermore, there are two models form of structural equations, then the form of the model figure chosen is a double lane model. Then, based on the research method above, the steps to present the path analysis results can be presented as follow.

The results of the study in table-1 for model-1 are to explore and examine how the influence of explanatory variables on entrepreneurial business opportunity variables in rural areas. While for model 2 is to explain the most influencing factors on the new institutional 
economy. Model-1 shows that social capital factor gives the first largest positive influence of 55 percent and are significant towards entrepreneurial business opportunities. In model1 , significant human capital factor is only able to make the second largest contribution that is 33.5 percent of entrepreneurial business opportunities. Meanwhile, the social network factor significantly only contributed a third of 14.1 percent to entrepreneurial business opportunities. In social theory, empirically, social capital is the basic values of local wisdom that have been inherent in almost all communities in rural areas in Indonesia. Although at present, the social capital value tends to decrease. The social capital values in this article are measured by the ratio between dimensions of the level of trust, volunteerism, social participation, tolerance and reciprocity as well as a sense of sympathy and empathy, have provided the main strength and entrepreneurial business opportunities. Furthermore, these social capital factors will form a social network within the community and strengthen shared knowledge and skills to increase the growth capacity for entrepreneurial business. Thus, the results of this research support previous research conducted by Raja (2014) stating that social capital is the main source of contribution to harmonious economic growth and encourages sustainable development. The results of this research also support Madriz's research (2018) which mention that human capital and social capital are drivers for entrepreneurship

\begin{tabular}{|c|c|c|c|c|c|c|}
\hline & \multirow[t]{2}{*}{ Model } & \multicolumn{2}{|c|}{$\begin{array}{l}\text { Unstandardized } \\
\text { Coefficients }\end{array}$} & \multirow{2}{*}{$\begin{array}{c}\begin{array}{c}\text { Standardized } \\
\text { Coefficients }\end{array} \\
\text { Beta }\end{array}$} & \multirow{2}{*}{ t-stc } & \multirow[t]{2}{*}{ Sig. } \\
\hline & & B & Std. Error & & & \\
\hline \multirow[t]{6}{*}{1} & (Constant) & -.046 & .029 & & $\begin{array}{c}- \\
1.575\end{array}$ & .118 \\
\hline & Human_capital (X1) & .352 & .056 & .335 & 6.230 & .000 \\
\hline & $\begin{array}{l}\text { Social_networking } \\
\text { (X2) }\end{array}$ & .168 & .066 & .141 & 2.537 & .012 \\
\hline & Social_capital (X3) & .633 & .069 & .550 & 9.219 & .000 \\
\hline & \multirow[t]{2}{*}{ Model } & \multicolumn{2}{|c|}{$\begin{array}{l}\text { Unstandardized } \\
\text { Coefficients }\end{array}$} & $\begin{array}{l}\text { Standardized } \\
\text { Coefficients }\end{array}$ & \multirow[t]{2}{*}{ t-stc } & \multirow{2}{*}{ Sig. } \\
\hline & & B & Std. Error & Beta & & \\
\hline \multirow[t]{4}{*}{2} & (Constant) & .198 & .020 & & 9.749 & .000 \\
\hline & Human_capital (X1) & .262 & .048 & .323 & 5.407 & .000 \\
\hline & Social_capital (X3) & .157 & .066 & .177 & 2.392 & .018 \\
\hline & Entrepreneurship (Y) & .368 & .066 & .476 & 5.552 & .000 \\
\hline
\end{tabular}

a. Dependent Variable: Entreprenurship (Y)

b. Dependent Variable: Institutional $(Z)$

c. All exogenous variables are significant for endogenous variables at level-1 (99\%)

Table 1. Multiple regression results against; entrepreneur and new institution economics.

In social analysis, social networks is a social structure that is formed by individual relations in a social organization because of the similarities in goals, vision, ideas, friends, harmony, and closeness. In social analysis, this social network is bound in which it also has rules of the game that must be maintained wiht full of awareness. Social relations formed through the spirit of entrepreneurship which is based on the uniqueness of social interaction "tuna satak bathi sanak". It is a new innovation to form a new economic and social 
institution that is believed to improve economic growth and welfare of the community (Prasetyo, 2019). In model-2, the result shows that the entrepreneurship (Y) factor has significantly been able to provide the first largest contribution of 47.6 percent to the formation of institutional $(Z)$. It indicates that increased capacity of entrepreneurs has encouraged the formation of new institutions in rural communities. Thus, the emergence of new social-economic institutions means that there has been an increase in capacity and capacity for social memory (Shvedosky, 2016).

In model-2, the human capital factor has significantly contributed to the second largest amount of 32.3 percent to the formation of a new institutional economy for playing an important role in improving its business. Meanwhile, social capital factors are proven to have declining contribution even though there was still a significant influence on the formation of a new institutional economy. Empirically, using the perspective of socioeconomic analysis, this phenomenon is natural and often occurs in real life. This already began since the process of social network interaction became increasingly widespread. Through participation and social network, they build social capital and new skills to improve human capital. The existing role of social capital might be still strong, but in the next process, when they began to develop new economic options as alternatives to new businesses and began to form new institutions, their role began to decline. Actually, the option for new institutions to be formed is to expand their business and simultaneously build joint physical and financial capital and to improve their environment. However, when economic business principles emerge and are dominant, then, the elements of the values of the formation of a social capital are slightly diminished. However, the results of this research are in line with previous research conducted by Cavaye (2006). Cavaye states that the development of local industries, including entrepreneurship in rural areas, involves relatively small industrial or institutional groups. Then, through participation and social networks, they build human capital to form larger institutions. However, the results of Cavaye's research did not explain quantitatively the impact on the social capital itself. In fact, the emergence of new social-economic institutions is built from the social capital in which, in economics, it can be as part of an influenceive knowledge management system although in the social system it can cause disruption of levels of resilience and vulnerability in social life.

Table 2. The partial correlation of the Pearson product moment matrix.

\begin{tabular}{|c|c|c|c|c|c|}
\hline & Model-1 & Entrepreneursh & Human_capit & Social_netwoki & Social_capital \\
\hline $\begin{array}{l}\text { Pearson } \\
\text { Correlatio }\end{array}$ & $\begin{array}{l}\text { Entrepreneurshi } \\
\mathrm{p}(\mathrm{Y})\end{array}$ & 1.000 & .671 & .580 & .800 \\
\hline $\mathrm{n}$ & $\begin{array}{l}\text { Human_capital } \\
\text { (X1) }\end{array}$ & .671 & 1.000 & .390 & .510 \\
\hline & $\begin{array}{l}\text { Social_networki } \\
\text { ng }(X \overline{2})\end{array}$ & .580 & .390 & 1.000 & .559 \\
\hline & $\begin{array}{l}\text { Social_capital } \\
\text { (X3) }\end{array}$ & .800 & .510 & .559 & 1.000 \\
\hline & Model-2 & NIE & $\begin{array}{c}\text { Human_capit } \\
\text { al }\end{array}$ & Social_capital & $\begin{array}{l}\text { Entrepreneursh } \\
\text { ip }\end{array}$ \\
\hline Pearson & NIE & 1.000 & .733 & .723 & .835 \\
\hline $\begin{array}{c}\text { Correlatio } \\
\mathrm{n}\end{array}$ & $\begin{array}{l}\text { Human_capital } \\
\text { (X1) }\end{array}$ & .733 & 1.000 & .510 & .671 \\
\hline & $\begin{array}{l}\text { Social_capital } \\
\text { (X3) }\end{array}$ & .723 & .510 & 1.000 & .800 \\
\hline & $\begin{array}{l}\text { Entrepreneurshi } \\
\mathrm{p}(\mathrm{Y})\end{array}$ & .835 & .671 & .800 & 1.000 \\
\hline
\end{tabular}


a. Dependent Variable: Entreprenurship (Y)

b. Dependent Variable: Institutional (Z)

c. All exogenous variables are significant with endogenous variables at level-1 (99\%)

Based on the partial matrix correlation values in table-2, both in model-1 and model-2, it shows the value that are still consistent with the results in table-1. In model-1, the value of social capital correlation still shows the strongest correlation with the level of entrepreneurial business opportunities in rural areas showing significant and strong correlation value of 80 percent. It means that social capital factors not only offer a large and significant level of influence on entrepreneurial business opportunities, but also strong and significant correlations between social capital factors and entrepreneurial business opportunities. Further, the problem of entrepreneurial business opportunities also significantly still has the first strongest level of correlation with the new institutional economy. In model-2, it is also interesting to see the level of correlation between social capital factors and the level of institutional economy. Although the magnitude of the level of influence of social capital has declined to the existence of a new institutional economy, the magnitude of the level of partial social capital correlation is still relatively strong and significant with a new institutional economic level of 72.3 percent, and only slightly with a strong and significant correlation value between level of human capital with a new institutional economic level of 73.3 percent. This phenomenon proves that the level of social capital factors has not been able to contribute to the increase in new institutional growth. However, it still has a strong and significant level of correlation. This means that the resilience of social capital factors is still good for the existence of new institutions produced.

There is an interesting thing to describe further in model-2, both in table 1 and 2. In model-2 in table-1, it shows the greatest and significant level influence between entrepreneurship and new economic institutions. Then, in table-2 there is also the strongest correlation between entrepreneurship and the new economic institution. The result shows that there is a causal relationship between entrepreneurship and new economic development. Thus, it supports previous research conducted by Elert (2017). The result of Elert's research (2017) show that it has contributed to the existing theory by passing an indepth analysis of entrepreneurial responses to institutions and finding a causal relationship between the two. Meanwhile, the results of Foss's research (2016), stated the opposite. The institutions will influence entrepreneurial activities more through the conditions of entrepreneurial action itself.

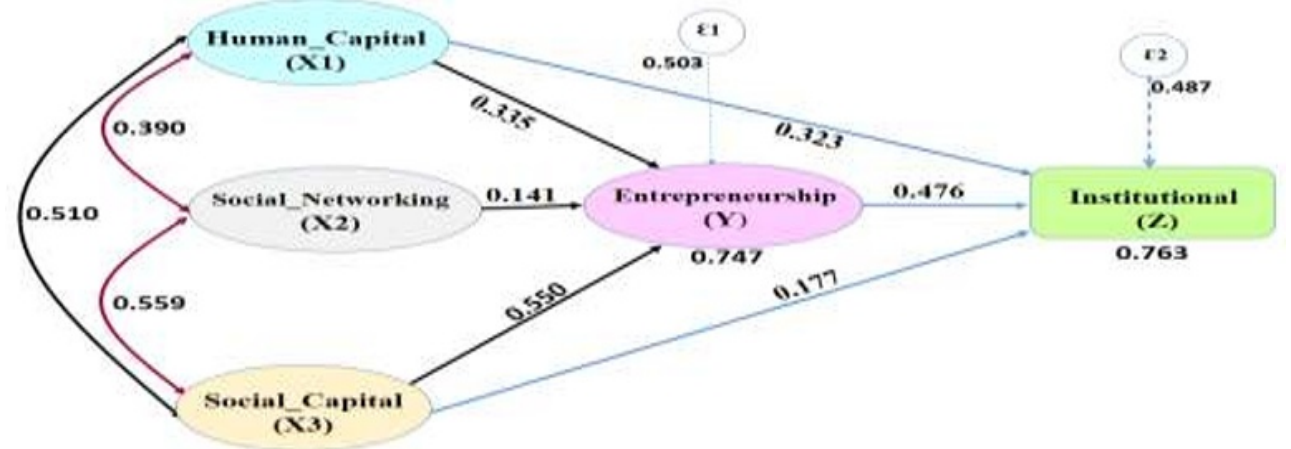

Fig. 3 The results of path analysis of the recrusive form correlation model with multiple path equations 
Based on the results of the research in table-1, and table-2, a basic framework for path analysis can be generated as illustrated in figure- 3 and tables-3. Figure- 3 describes the form of multiple path analysis model correlation lines. Based on figure- 3 , it can be seen that the direction of the arrows of each exogenous variable regarding the new institutional endogenous economic vaiebel has a direct and indirect influence. Furthermore, the results of multiplication of values in figure-3 will be obtained in the angular form values as in table-3. Figure- 3 shows that that the direct influence of human capital and social capital factors is greater than the influence of human capital and social capital factors on institutions. However, the decline in the value of social capital appears to be greater, from 55.0 percent to 17.7 percent, compared to the decline in value in human capital, namely from 33.5 percent to 32.3 percent. The phenomenon of the results of this research supports the previous research conducted by Bosma, (2018). Bosma's research (2018) found that when entrepreneurial channel for quality, and variations in national economic growth increase, the importance of human capital is proven to be reduced

Table 3. The results of direct influence, indirect influence and total influence

\begin{tabular}{|c|c|c|c|c|c|c|c|}
\hline \multirow{2}{*}{ Variabel } & \multirow{2}{*}{$\begin{array}{c}\text { Direct } \\
\text { influence }\end{array}$} & \multicolumn{4}{|c|}{ Indirect influence } & \multirow{2}{*}{$\begin{array}{l}\text { Indirect } \\
\text { influence }\end{array}$} & \multirow{2}{*}{\begin{tabular}{|l} 
Total \\
influence
\end{tabular}} \\
\hline & & $\mathrm{HC}$ & SN & $\mathrm{SC}$ & $\mathrm{EO}$ & & \\
\hline $\begin{array}{l}\text { Human_capital } \\
\text { (HC) }\end{array}$ & 0.104 & & 0.009 & 0.029 & 0.052 & 0.090 & 0.142 \\
\hline $\begin{array}{l}\text { Social_networking } \\
\text { (SN) }\end{array}$ & 0.020 & 0.009 & & 0.007 & 0.003 & 0.010 & 0.013 \\
\hline Socal_capital (SC) & 0.031 & 0.029 & 0.007 & & 0.046 & 0.082 & 0.128 \\
\hline $\begin{array}{l}\text { Entrepren_opport } \\
\text { (EO) }\end{array}$ & 0.226 & 0.052 & 0.003 & 0.046 & & 0.101 & 0.327 \\
\hline \multicolumn{7}{|c|}{ Total } & 0.610 \\
\hline
\end{tabular}

Then, various processes of in-depth study of the level of partial correlation and the level of influence partially and the path analysis model are performed as in figure 3 , the value of the results of path analysis can be obtained as in table-3. Table-3 illustrates obvious degree of direct influence, indirect influence and total influence of exogenous variables on new institutional endogenous economic variables. Table-3 shows that entrepreneurial business opportunity factors are able to provide the first biggest influence either direct, indirect and total influence, each of which is equal to; 22.6 percent; 10.1 percent; and 32.7 percent. Further, social capital factors are also interesting issues. Social capital factors are still able to give a total influence on institutions at 12.8 percent. However, it turned out that the indirect influence was even greater at 8.2 percent, rather than the direct influence of only 3.1 percent. Whereas, the human capital factor is able to give a total influence on institutions which is equal to 14.2 percent, slightly higher than the influence of social capital. However, the human capital factor also still offers a greater level of direct influence of 10.4 percent and an indirect influence of only 9.0 percent. The phenomenon of the magnitude of the influence of social capital turns out to occur at the initial level, when business begins to expand, the social capital role decreases

\section{Conclusion}

The author has not only examined the role of social capital, human capital and networking on entrepreneurship, but also the role of the existence of entrepreneurial businesses on institutions. The results show that there were strong and significant positive relationships, and significant positive influences between social capital, human capital and networking on entrepreneurship. Further, there is also a strong positive relationship and significant; human capital, social capital and entrepreneurship on with a new institutional economics. I suggest that it is important to further study how the causality relationship and the influence of institutions on entrepreneurship and economic growth. Also, it is necessary to examine how the new institutional economic quality of the institution is able to encourage productive entrepreneurship and encourage economic growth. This is due to good economic 
development should be able to create social equity. Development must also consider humans as the subject of development and not as objects. Through the development of entrepreneurship and institutions, the level of economic growth can still be significantly improved towards a better one. Hence, it is recommended that a serious policy commitment should be made to improve human capital capacity and strengthen social capital. If entrepreneurship and institutions are strong the improved capacity of human and social capital, it can increase human resource quality, better understanding on humanistic principles, and sustainable economic growth

\section{Acknowledgement}

We are very grateful to the Directorate General of Strengthening for Research and Development, Ministry of Education of the Republic of Indonesia (DRPM DIKTI), who has provided financial assistance in conducting research, especially in the PDUPT decentralization research scheme for the years 2019-2021 with contract numbers: 192 / SP2h / LT / DRPM / 2019

\section{References}

1. D. Acemoglu, S. Johnson, and J. Robinson, Am. Econ. Rev. 95, 3 (2005)

2. A. K. Ali and A. E. Mansur, Potential Soc. Cap. Community Dev. Eds. Yokoyama, S. Al., Asian Product. Organ. (2006)

3. N. Bosma, J. Content, M. Sanders, and E. Stam, Small Bus. Econ. (2018)

4. G. D. Bruton, D. Ahlstrom, and H. Li, Entrep. Theory Pract. 34, 421 (2010)

5. J. Cavaye, (2006)

6. M. Chibba, World Econ. 9, 1 (2008)

7. N. Elert and M. Henrekson, Found. Trends Entrep. (2017)

8. S. Estrin, T. Mickiewicz, and U. Stephan, J. Bus. Ventur. 31, 449-467 (2016)

9. C. Bjørnskov and N. J. Foss, in Acad. Manag. Perspect. 20, 3 (2016)

10. J. Kim and J. T. Mahoney, Manag. Decis. Econ. 26, 223-242 (2005)

11. A.-L. A. LATOPA and S. M. Bashir, Conf. Pap. Present. 2015 (n.d.)

12. C. Madriz, J. C. Leiva, and R. Henn, Small Bus. Int. Rev. 2, 29-42 (2018)

13. J. E. Meador and S. Skerratt, J. Rural Stud. 53, 144-155 (2017)

14. C. Ménard, RAUSP Manag. J. 53, 3 (2018)

15. F. Murgaš and H. Böhm, 15th Int. Multidiscip. Sci. GeoConference SGEM 2015. 3, 213-220 (2015)

16. T. Netar, (2017)

17. D. C. North, Int. Libr. Crit. WRITINGS Econ. 84, 3 (1994).

18. D. C. North, New Institutional Econ. Third World Dev. 21, 31-40 (2003)

19. P. E. Prasetyo, Int. J. Econ. Financ. Issues 9, 3 (2019)

20. P. Raja, Pertanika J. Soc. Sci Hum 22, 97-110 (2014)

21. .R. Richter, Eur. Bus. Organ. Law Rev. 6, 161-200 (2005)

22. M. Rutherford, J. Econ. Perspect. 15, 3 (2001)

23. D. Seers, Dev. Theory Four Crit. Stud. 9 (1979) 
24. D. S. Kraybill, (1990)

25. V. Shvedovsky, A. Standrik, and Y. Bilan, Econ. Sociol. 9, 2 (2016).

26. V. O. T. Thanh12 and N. A. Duong, (2016)

27. O. E. Williamson, J. Econ. Lit. 38, 3 (2000)

28. O. E. Williamson, The Economic Institutions of Capitalism: Firms, Markets, Relational Contracting (Free Press, 1985).

29. A. Yildirim and M. F. Gokalp, Procedia Econ. Financ. 38, 347-359 (2016) 